\title{
EFFECTIVENESS OF HIGH INPUT FEEDING SYSTEM IN RELATION TO GROWTH AND CARCASS QUALITY OF VARIOUS CLASSES OF BEETAL KIDS
}

\author{
Kashif Ishaq1, ${ }^{1, *}$,Muhammad Younas ${ }^{1}$, Muhammad Riaz $^{2}$ and Mubarak $\mathrm{Ali}^{2}$ \\ ${ }^{1}$ Institute of Dairy Sciences, University of Agriculture, Faisalabad-Pakistan; \\ ${ }^{2}$ Institute of Animal Sciences, University of Agriculture Faisalabad-Pakistan. \\ "Corresponding author's e-mail: drkashif@uaar.edu.pk
}

\begin{abstract}
High input feeding system results in better growth performance in goats as compared to low input feeding system. Traditionally goats are reared under low input system while to see the effectiveness of high input feeding system, current project was planned to study the growth performance and carcass quality among various classes of Beetal breed. Total 16 Beetal kids (12 male +4 female) were selected considering $120( \pm 10)$ days average age and weight ranging $16( \pm 2) \mathrm{kg}$ for male and $14( \pm 2) \mathrm{kg}$ for female. The kids from various classes were divided into four treatment groups designated as S1 (Entire male or not castrated), $\mathrm{S} 2$ (castrated at $4 \mathrm{mo}$ ), S3 (castrated at $6 \mathrm{mo}$ ) and S4 (female). Animals were castrated during pre-fattening period and managed under same conditions before fattening. The duration of the study was 120 days (60 days pre-fattening +60 day fattening). Total 12 animals (randomly 3 from each treatment group) were slaughtered at the end of study for detail carcass quality evaluation. The average daily gain $(\mathrm{ADG})$ was significantly affected $(\mathrm{P}<0.001)$ by the treatments. There was higher ADG noticed in S3 group $(93.75 \mathrm{gm} / \mathrm{d})$ as compared to S1 $(90.42 \mathrm{gm} / \mathrm{d}), \mathrm{S} 4(63.89 \mathrm{gm} / \mathrm{d})$ and $\mathrm{S} 2(33.75 \mathrm{gm} / \mathrm{d})$. Average daily feed intake was significantly $(\mathrm{P}<0.05)$ highest in $\mathrm{S} 3(878.00 \mathrm{gm} / \mathrm{d})$. The serum cholesterol and serum glucose were also affected $(\mathrm{P}<0.05)$ by the treatments. There was non-significant $(\mathrm{P}>0.05)$ effect of treatments on the sensory panel score about color, chewability, flavor, tenderness and overall acceptability of the cooked meat. It is concluded that sex and castration affected the growth in kids while the carcass traits were not affected. The age of castration need consideration in Beetal kids because castration at early age adversely affected the growth of kids in this study.
\end{abstract}

Keywords: Beetal kids, castration, carcass, sensory evaluation, blood metabolites.

\section{INTRODUCTION}

Improvement of the meat quality and quantity cannot be overemphasized to meet the international nutritional standards for the people in Pakistan who are deficient in animal protein by consuming $18 \mathrm{gm} / \mathrm{capita} / \mathrm{year}$ (Ali and Khan, 2013). The meat from goat has better demand and price in the local market because of more preference by majority of people (Arain et al., 2010). The Beetal is one of the most popular breed of goat in the local sooqs due to its beauty, better growth rate and meat demand especially at eve of Eidul-Adha (Khan et al., 2005).

Traditionally, the small ruminants are raised on the low input feeding system, which results in lower growth of the animals (Sarwar et al., 2010). In some recent studies, high inputfeeding system has been found to be more efficient in enhancing the growth performance of Beetal by improving the nutrient availability (Nisa et al., 2013; Sarwar et al., 2012; Mukhtar et al., 2010). Many studies showed that the carcass quality are imperative to figure out growth performance in goats (Oramari, et al., 2014; Najafi et al., 2012; Limea et al., 2009; Titi et al., 2008). The scanty information is available about the carcass characteristics of Beetal goat. The current study is a step forward to explore the effectiveness of high input feeding system while considering about the growth and carcass quality analysis simultaneously.

The meat available in the markets are from the various classes i.e. castrated male, entire or non-castrated male and female animals. There are fair amount of studies which depicts about the consideration of various factors like sex, castration, age of castration, type and breed while studying the growth, carcass traits and attributes of meat (Alkass et al., 2014; Ozcan et al., 2014; Mudalal et al., 2014; Poore et al., 2013; Ekiz et al., 2009; Lambe et al., 2009). The information on aforementioned factors is flimsy regarding Beetal breed especially while raising them under high input feeding system. Thus the data generated during current study will be helpful not only to validate the utility of high input feeding system but also to compare the carcass attributes of various classes of Beetal kids.

\section{MATERIALS AND METHODS}

Selection of animals: The study was conducted at Livestock Experiment Station (LES), Allahdad, Tehsil Jahania, District Khanewal. Total 16 Beetal kids $(12 \hat{\jmath}+4$ $)$ were selected. 
The age of all the animals were $120( \pm 10)$ days while the weight of the animals were $16( \pm 2) \mathrm{kg}$ for males and $14( \pm 2)$ $\mathrm{kg}$ for female group. All animals were grouped into four animal class types designated as S1 (4 male entire), S2 (4 male castrated at $4 \mathrm{mo}$ ), S3 (4 male castrated at six mo) and S4 (4 female).

Pre-fattening management: The S2 group was castrated at 120 days of age while S3 group was castrated at 180 days of age. All the animals were grown on Maize fodder (Zea mays) for two months (60 days) and managed on same conditions before fattening.

Fattening: After completion of growing period at 180 days of age, all the experimental units were fattened on the pelleted feed under high input feeding systems (Table 1). Animal were offered ad-libitum feeding and watering for $24 \mathrm{hrs}$ in individual pens. The duration of this phase was 60 days including 7 days adjustment period at start of fattening.

Table 1. Ingredient and Chemical composition of ration.

\begin{tabular}{lc}
\hline Ingredient & Inclusion level (\%) \\
\hline Maize (yellow hybrid) & 10 \\
Oats & 30 \\
Corn Gluten Feed $(30 \%)$ & 5 \\
Rice Polishing & 12 \\
Wheat Bran & 20 \\
Molasses & 08 \\
Wheat Straw & 12 \\
Oil & 1 \\
Lime stone & 1 \\
Salt & 1 \\
\hline
\end{tabular}

\begin{tabular}{lc}
\hline Chemical composition (\%) & 1 \\
Proximate composition & \\
Dry matter & 90.80 \\
Crude Protein & 10.85 \\
Ether Extract & 6.58 \\
Crude Fiber & 14.55 \\
Ash & 9.75 \\
NFE & 58.27 \\
\hline NDF & 25.75 \\
ADF & 16.40 \\
Gross Energy $(\mathrm{Mcal} / \mathrm{Kg})$ & 3.55 \\
\hline Note: Derived from $N R C(2007)$
\end{tabular}

Note: Derived from NRC (2007)

Statistical design: The animals were exposed to treatment under completely randomized design. The model equation is given below.

$$
Y_{i, j}=\mu+(\text { Class of Animal })_{i}+\epsilon_{i, j}
$$

Data collection: The data were collected on body weight, fattening ration intake, blood metabolites, slaughter and carcass traits. Body weight were measured weekly. Daily orts were collected to measure feed intake during fattening period. Average daily gain (Kadim et al., 2003), feed conversion ratio (Sen et al., 2004) and Kleiber ratio (Mohammadi et al., 2010) were calculated at the end of the trial. Blood samples were collected at day one and at the end of the fattening period for determining serum glucose, serum creatinine, blood urea nitrogen (BUN) and cholesterol to know the physiological response in treatment groups (Nudda et al., 2013).

The fattening ration and minced meat sample were analyzed by proximate analyses procedures detailed out by AOAC (2003) for determining the detail chemical composition at Institute of Animal Nutrition and Feed Technology (IAN\&FT), UAF. Twelve animals (3 from each group) selected randomly for slaughtering at the end of the experiment, were transported to the University of Agriculture, Faisalabad, through vehicle. The duration of journey was 6 hours. The animals were given rest, water and feed after 3 hours. Final weights of all animals were recorded after $12 \mathrm{hr}$ fasting and then after $24 \mathrm{hr}$ fasting prior to slaughter. Hot carcass weight was recorded after excluding the weight of testes, kidney, pelvic fat and tail and used to calculate the dressing percentage (Bonvillani et al., 2010). The carcasses were chilled for $24 \mathrm{hr}$ at $4{ }^{\circ} \mathrm{C}$ and weight was recorded. The carcasses were split into two symmetrical parts with the aid of meat saw. Then left side carcasses were frozen at $-20^{\circ} \mathrm{C}$ (aged for 30 day). The rib eye muscle from aged carcasses were used for further meat tests and sensory evaluation at National Institute of Food Science and Technology (NIFSAT), UAF, except meat colour index which was performed at Ayub Agri Research Institute, Faisalabad. The eye muscle or ribeye area was determined between $12-13^{\text {th }}$ rib by Grid-EMA while following Plant and Maden (1996). The meat was thawed, minced and used for determination of $\mathrm{pH}$ by slurry method using Hanna Instruments (HI 98107 pHep $\mathrm{pH}$ Tester, +/-0.1 Accuracy). The $\mathrm{pH}$ of meat was evaluated by taking $10 \mathrm{gm}$ of the minced meat samples and homogenized in $100 \mathrm{ml}$ of distilled water for about 30 seconds at high speed. Homogenized samples were transferred into a beaker and $\mathrm{pH}$ was noted by placing the $\mathrm{pH}$ electrode into the samples (Arain et al., 2010).

Tenderness (using TA.XT.PLUS Texture Analyzer) were measured while following the protocols as described by Cavitt et al. (2005) with some modifications. Meat piece from the loin part (longissimus dorsi) was used to determine the force (in $\mathrm{kg} / \mathrm{cm}^{2}$ ) with needle puncture shear force Texture Analyzer having a 5-kg load cell using a needle puncture probe with a height of $25 \mathrm{~mm}$ and a diameter of $2 \mathrm{~mm}$ set to a penetration depth of $20 \mathrm{~mm}$. Crosshead speed was set at 80 $\mathrm{mm} / \mathrm{min}$ and the test was triggered by a 10 -g contact force. Water Holding Capacity (WHC) was determined according to the procedure described by Wardlaw et al. (1973) with some modifications. The frozen right fillets were thawed at $4^{\circ} \mathrm{C}$ for $8 \mathrm{hrs}$ in a refrigerator. The loin area meat were cut and ground for $1 \mathrm{~min}$ in a food processor to achieve the desired particle size of approximately $3 \mathrm{~mm}$ of diameter. Five gram portions of the ground meat were weighted and placed in $35 \mathrm{ml}$ assay tubes containing $80 \mathrm{ml}$ of $0.6 \mathrm{M} \mathrm{NaCl}$. The solution was mixed for $30 \mathrm{sec}$, incubated for $30 \mathrm{~min}$ at $4{ }^{\circ} \mathrm{C}$ and centrifuged 
at $5000 \mathrm{rpm}$ for $15 \mathrm{~min}$. After centrifugation, the volume of the supernatant was measured using a $10 \mathrm{ml}$ volumetric cylinder.

Cooking loss (\%) was measured following Kondaiah et al. (1985) by placing meat sample (20 gm) was placed in polyethylene bag and heated in a water bath at internal temperature of $72^{\circ} \mathrm{C}$. Cook-out was drained and the cooked mass was cooled and weighed to determine the weight loss.

Drip loss (\%) was determined according to the procedure described by Earl et al. (1996) with some modifications. Three pieces of Whatman 14 \# 3 paper $(5.5 \mathrm{~cm})$ and one piece of Whatman \# 50 filter paper $(7.0 \mathrm{~cm})$ were formed into a thimble by shaping the filter papers around the outer round bottom of an inverted $16 \times 150 \mathrm{~mm}$ test tube with the \# 50 filter paper as the internal surface of the thimble. The filter paper thimble was weighed and approximately 5 gm of ground meat wrapped and folded in a $15 \mathrm{~cm}^{2}$ piece of $0.1 \mathrm{~mm}$ mesh white tulle netting was placed inside the thimble and then stored at $4^{\circ} \mathrm{C}$ for $24 \mathrm{hrs}$. The filter paper with moisture was weighed and expressible moisture was reported as the percentage weight lost from the original samples.
The Color index ( $L, a^{*}, b^{*}$ values) of meat samples were measured after blooming the meat samples using Minolta Chroma Meter CR-200 (Accuracy Microsensors, Inc., USA). These color index values were used to calculate the chromaticity and hue angle (Caneque et al., 2004). The meat samples were analyzed for chemical composition by proximate analysis procedures (AOAC, 2003). The sensory evaluation of the cooked meat samples (by boiling while following Eneji et al., 2012) was carried out by eight trained panelists (within the age range of 25-40 years) for different attributes like appearance, flavor, juiciness, chewiness and overall acceptability by using nine point hedonic scales following the method described by Meilgaard et al. (2007).

Statistical analysis: The data were analysed using linear model procedures run in R-software (3.0.3 version). The means were compared by Tukey's HSD test during post-hoc analyses (R Core Team, 2014).

\section{RESULTS}

The statistical analysis of data (Table 2) showed that the ADG

Table 2. Growth performance and carcass characteristics of various classes of Beetal kids under high input feeding system.

\begin{tabular}{|c|c|c|c|c|c|c|c|}
\hline \multirow[t]{2}{*}{ Response Factor } & \multirow[t]{2}{*}{ Parameters (Units) } & \multicolumn{4}{|c|}{ Classes of Beetal Kids (Treatment) } & \multirow[t]{2}{*}{ P-Value } & \multirow[t]{2}{*}{ SEM } \\
\hline & & $\overline{\text { S1* }}$ & $\mathbf{S 2} * *$ & S3*** & $\mathbf{S 4} * * * *$ & & \\
\hline Growth Performance & Av, daily gain $(\mathrm{gm} / \mathrm{d})$ & $90.42 \mathrm{a}$ & $33.75 b$ & $93.75 a$ & $63.89 \mathrm{~b}$ & $\mathrm{P}<0.001$ & 10.75 \\
\hline \multirow[t]{2}{*}{ (Fattening Stage) } & Klieber ratio & $7.54 \mathrm{a}$ & $3.87 \mathrm{~b}$ & $8.56 \mathrm{a}$ & $7.07 \mathrm{a}$ & $\mathrm{P}=0.002$ & 0.966 \\
\hline & Av. daily feed intake (gm/d) & $743.5 \mathrm{a}$ & $307.5 b$ & $878 \mathrm{a}$ & $739 a$ & $\mathrm{P}<0.01$ & 58.71 \\
\hline \multirow[t]{2}{*}{ Slaughter Traits } & Hot carcass wt. (kg) & $9.66 \mathrm{a}$ & $7.00 \mathrm{~b}$ & $12.67 \mathrm{a}$ & $11.25 \mathrm{a}$ & $\mathrm{P}<0.05$ & 1.122 \\
\hline & Dressing $(\%)$ & $48.96 \mathrm{~b}$ & $39.89 c$ & $51.51 b$ & $58.38 \mathrm{a}$ & $\mathrm{P}<0.001$ & 1.933 \\
\hline \multirow{10}{*}{ Carcass Traits } & Cold carcass wt. $(\mathrm{kg})$ & $9.33 \mathrm{ab}$ & $6.91 b$ & $12.33 \mathrm{a}$ & $10.88 \mathrm{ab}$ & $\mathrm{P}<0.001$ & 1.159 \\
\hline & Eye area (sq. In) & 1.83 & 1.20 & 2.20 & 1.20 & $\mathrm{P}>0.05$ & 0.481 \\
\hline & $\mathrm{pH}$ of meat & 5.63 & 5.60 & 5.47 & 5.50 & $\mathrm{P}>0.05$ & 0.446 \\
\hline & Tenderness/Needle Puncture $(\mathrm{kg} / \mathrm{cm})$ & 0.73 & 0.38 & 0.48 & 0.44 & $\mathrm{P}>0.05$ & 0.056 \\
\hline & Water holding capacity & 57.22 & 54.50 & 56.67 & 51.11 & $\mathrm{P}>0.05$ & 3.181 \\
\hline & Cooking loss $(\%)$ & 31.40 & 33.60 & 33.02 & 30.93 & $P>0.05$ & 2.253 \\
\hline & Drip loss $(\%)$ & $1.34 \mathrm{ab}$ & $2.32 \mathrm{a}$ & $2.15 \mathrm{a}$ & $0.81 \mathrm{~b}$ & $\mathrm{P}<0.05$ & 0.391 \\
\hline & Hue angle & $19.09 \mathrm{ab}$ & $14.97 \mathrm{~b}$ & $17.14 \mathrm{a}$ & $16.87 \mathrm{ab}$ & $\mathrm{P}<0.05$ & 0.150 \\
\hline & Lightness & 41.28 & 44.18 & 44.03 & 41.59 & $\mathrm{P}>0.05$ & 2.845 \\
\hline & Chromaticity & 29.41 & 28.40 & 32 & 31.36 & $\mathrm{P}>0.05$ & 4.583 \\
\hline Meat Composition & Moisture (\%) & 72.61 & 76.32 & 75.68 & 74.50 & $P>0.05$ & 3.190 \\
\hline \multirow[t]{3}{*}{ (\% of Fresh meat) } & Fat by Ether extract method (\%) & 5.67 & 5.33 & 5.83 & 5.67 & $\mathrm{P}>0.05$ & 0.499 \\
\hline & $\mathrm{CP}(\%)$ & 17.94 & 18.32 & 18.20 & 18.00 & $\mathrm{P}>0.05$ & 0.165 \\
\hline & $\operatorname{Ash}(\%)$ & 1.70 & 1.50 & 1.50 & 1.33 & $\mathrm{P}>0.05$ & 0.996 \\
\hline Sensory Evaluation & Color & 7.04 & 6.75 & 7.08 & 7.17 & $\mathrm{P}>0.05$ & 0.254 \\
\hline \multirow[t]{5}{*}{ (Average Panel Score) } & Texture & 6.92 & 7.00 & 6.92 & 5.83 & $\mathrm{P}>0.05$ & 0.556 \\
\hline & Flavor & 6.75 & 6.79 & 6.46 & 6.50 & $\mathrm{P}>0.05$ & 0.661 \\
\hline & Juiciness & 6.54 & 6.88 & 6.96 & 6.58 & $\mathrm{P}>0.05$ & 0.406 \\
\hline & Chewability & 6.83 & 7.04 & 7.17 & 7.17 & $\mathrm{P}>0.05$ & 0.312 \\
\hline & Overall acceptability & 6.76 & 6.94 & 6.97 & 6.30 & $\mathrm{P}>0.05$ & 0.273 \\
\hline \multirow[t]{4}{*}{ Blood Metabolites } & Serum glucose (mg/dl) & $42.50 \mathrm{ab}$ & $52.25 \mathrm{ab}$ & $59.25 \mathrm{a}$ & $38.25 b$ & $\mathrm{P}<0.05$ & 5.885 \\
\hline & Blood urea nitrogen $(\mathrm{mg} / \mathrm{dl})$ & 7.68 & 9.75 & 10.05 & 8.84 & $\mathrm{P}>0.05$ & 1.121 \\
\hline & Serum cholesterol $(\mathrm{mg} / \mathrm{dl})$ & $71.00 \mathrm{ab}$ & $64.00 \mathrm{~b}$ & $90.50 \mathrm{a}$ & $55.50 \mathrm{~b}$ & $\mathrm{P}<0.01$ & 7.530 \\
\hline & Serum creatinine $(\mathrm{mg} / \mathrm{dl})$ & $0.235 b$ & $0.174 \mathrm{c}$ & $0.279 \mathrm{a}$ & $0.238 \mathrm{ab}$ & $\mathrm{P}<0.001$ & 0.014 \\
\hline
\end{tabular}

Note: Superscript of means (a,b,c) shows the means comparison by Tukey's HSD test. Where same alphabet means no difference. *Entire male, **Castrated at 4 month age, ***Castrated at 6 month age, ****Female. 
of Beetal kids were significantly $(\mathrm{P}<0.001)$ affected by the class of the animals. The detail post hoc analysis showed that overall males showed better ADG than female group. Within the males, S3 $(93.75 \mathrm{gm} / \mathrm{d})$ had shown highest ADG followed by S1 $(90.42 \mathrm{gm} / \mathrm{d})$ and S2 (33.75 gm/d). However, Tukey's HSD test revealed that $\mathrm{S} 3$ had non-significant $(\mathrm{P}>0.05)$ difference with S1. Similarly, the Klieber ratio calculations also validated that the $\mathrm{S} 3$ group had shown better performance $(\mathrm{P}<0.05)$ than other classes. Average daily feed intake (ADFI) was significantly $(\mathrm{P}<0.001)$ affected by the treatment groups. S2 group had showed lowest average feed intake (307.50 $\mathrm{gm} / \mathrm{d})$ than rest of the groups. Class of animals significantly $(\mathrm{P}<0.001)$ affected the dressing percentage. S3 and S4 had shown better dressing percentage $51.51 \%$ and $58.38 \%$, respectively, followed by S1 (48.96\%) and S2 (39.89\%). The hot carcass showed significant effect of the treatments. It was least in $\mathrm{S} 1(7 \mathrm{~kg})$ and highest in $\mathrm{S} 2(12.61 \mathrm{~kg})$.

However, the detailed carcass analyses showed that except the hot carcass weight, cold carcass weight, hue angle and drip loss all other parameters were not different $(\mathrm{P}>0.05)$ among treatment groups. The drip loss was highest $(\mathrm{P}<0.05)$ in $\mathrm{S} 2$ $(2.32 \%)$ and lowest in S1 and S4 groups. It was also proved by the outcomes during meat composition and sensory evaluation by the expert panel using 9 point hedonic scale exhibited no difference of carcass fattened on iso-caloric and iso-nitrogenous rations. It was further found that the castration and sex of animals did not affect the carcass traits during the current experiment.

The class of the Beetal affected $(\mathrm{P}<0.05)$ the serum glucose levels. Within the male the serum glucose was nonsignificantly different while female group (S4) had least serum glucose $(38.25 \mathrm{mg} / \mathrm{dl})$. Blood urea nitrogen (BUN) was not affected $(\mathrm{P}>0.05)$ by the class of animals. The serum creatinine and cholesterol were significantly affected by the treatments. The S3 group showed higher serum cholesterol $(90.50 \mathrm{mg} / \mathrm{dl})$ followed by $\mathrm{S} 1$ (71 mg/dl), S2 (64 mg/dl) and $\mathrm{S} 4(55.50 \mathrm{mg} / \mathrm{dl})$. Serum creatinine was least in S2 group $(0.174 \mathrm{mg} / \mathrm{dl})$ while $\mathrm{S} 2$ showed highest level of serum creatinine $(0.279 \mathrm{mg} / \mathrm{dl})$ during current study.

\section{DISCUSSION}

There was significant effect of treatments on the average daily gain (ADG), average daily feed intake (ADFI) and Klieber ratio. The age of castration affected significantly the ADG and ADFI. The animals castrated at 4 month of age (S2) showed less ADG and ADFI as compare to animals castrated at 6 month of age (S3). The reason could be the more average daily feed intake which resulted in more nutrient available for growth. The early age castration might have affected the intake and overall lower the metabolism which resulted in the lower ADG in S2 (Schanbacher et al., 1980). The Kleiber ratio followed the same trend as of ADG with higher the ratio shows better feed conversion (Talebi, 2012).
The age of castration and sex significantly affected the dressing percentage and hot carcass weight. Females had shown better dressing percentage than males. Overall the dressing percentage was not affected by the castration rather age of castration was responsible for lower dressing percentage in S2 while S2 and S1 were same when Tukey's HSD used to compare the means. It was because of depressed growth performance of the S2 group due to early age castration (Zamiri et al., 2012). This early age castration could result in decrease IGF-1 as there has been strong relation between the testosterone and IGF-1 reported by Bani Ismail et al. (2009).

Hot and cold carcass weights were more in S3 groups mainly due to better ADG performance (Gokdal, 2013). However, hue angle was less in S2 as compared to other classes which showed statistically same hue angle values when the means were compared by Tukey's HSD test. The castration at 4 mo age resulted in lower glycogen content which may be responsible for lower hue angle value (Ripoll et al., 2008). Higher value of drip loss in S2 group was due to lower water holding capacity of meat as water holding capacity was decreased due to lower growth performance of the S2 (Hwangbo et al., 2009).

Other carcass attributes showed the non-significant effect of the class of animals because the sex and castration did not result in fat deposition at this age of animals and could be due to fattening period was less than 5 months (Zamiri et al., 2012). Similarly, the sensory evaluation score by the expert panels also showed the non-significant effect of the class of the animals on the meat color, chewability, tenderness, flavor and over all acceptability could be due to aforementioned reasons.

Serum glucose was lower in female animals as compared to male which showed that the more nutrient intake for male as evident in ADFI (Turner et al., 2005). While BUN was not significantly different among the treatment groups because of iso-nitrogenous fattening ration (Kadzere and Charama, 1992; Karnezos et al., 1994). The serum cholesterol was highest in S1 and S4 mainly due to better growth performance as better ADG performance of these groups might be responsible for higher levels of the cholesterol in serum (Tripathi et al., 2012). High creatinine shows high muscle mass metabolism and this is obvious as S3 group has better ADG and ADFI (Sun and Zhou, 2010; Wellington et al., 2003).

Conclusion: From the study it can be extracted that growth performance was affected by the classes of Beetal kids while the carcass evaluation, chemical composition and sensory evaluation showed non-significant effect among the various classes. Therefore, all the classes of kids hold a strong scope for rearing under high input feeding system till 8 months of age, however, the effect on carcass traits during fattening need further investigations. The castration at early age resulted in 
lower growth as well as low quality carcass but late castration provides a better performance and good meat quality.

Acknowledgments: We acknowledge Pakistan Science Foundation (PSF) and Higher Education Commission (HEC), Islamabad, Pakistan for financial support and also thank the Directorate of Small Ruminant Production, Multan for helping us to conduct the study.

\section{REFERENCES}

Ali, A. and M.A. Khan. 2013. Livestock ownership in ensuring rural household food security in Pak. J. Anim. Plant Sci. 23: 313-318.

Alkass, J.E., K.A.D. Oras and M.K. Abdulla. 2014. Studies on growth, carcass traits and body composition of goats raised either in intensive or pasture conditions (1-growth performance and carcass traits). J. Biol. Agric. Healthcare 4: 45-53.

AOAC. 2003. Official Methods of Analysis of AOAC International, $17^{\text {th }}$ Ed. Tech. Rep. Gaithersburg, MD, USA.

Arain, M.A., M. Khaskheli, I.R. Rajput, S. Rao, S. Faraz, S.A. Fazlani, K. Devrajani and M. Umer. 2010. Examination of physical properties of goat meat. Pak. J. Nutr. 9: 422425.

Bani Ismail, Z., O.M. Al-Ababneh and M.B. Al-Zghoul. 2009. Serum levels of insulin-like growth factor-I, thyroid hormones and skeletal muscle fiber size in castrated lambs with and without androgen treatment. Am. J. Applied. Sci. 6: 518-522.

Bonvillani, A., F. Pena, G. deGea, G. Gomez, A. Petryna and J. Perea. 2010. Carcass characteristics of Criollo Cordobes kid goats under an extensive management system: Effects of gender and liveweight at slaughter. Meat Sci. 86: 651-659.

Caneque, V., C. Perez, S. Velasco, M. T. Diaz, S. Lauzurica, I. Alvarez, F. Ruiz deHuidobro, E Onega and J. De-laFuente. 2004. Carcass and meat quality of light lambs using principal component analysis. Meat Sci. 67: 595605.

Cavitt, L.C., J.F. Meullenet, R.K. Gandhapuneni, G.W. Youm and C.M. Owens. 2005. Rigor development and meat quality of large and small broilers and the use of AlloKramer shear, needle puncture and razor blade shear to measure texture. Poult. Sci. 84: 113-118.

Earl, L.A., A.J. King, D.P. Fitzpatrick and J.E. Cooper. 1996. A modification of a method to determine expressible moisture in ground, dark Poultry meat. Poult. Sci. 75: 1433-1436.

Ekiz, B., A. Yilmaz, M. Ozcan, C. Kaptan, H. Hanoglu, I. Erdogan and H. Yalcintan. 2009. Carcass measurements and meat quality of Turkish Merino, Ramlic, Kivircik,
Chios and Imroz lambs raised under an intensive production system. Meat Sci. 82: 64-70.

Eneji, C.A., G.A. Kalio and O.O.K. Oko. 2012. Sensory evaluation of meat of west African Dwarf goats fed crop by-products in Cross River State, Nigeria. J. Agric. Sci. 4: 201-202.

Gokdal, O. 2013. Growth, slaughter and carcass characteristics of Alpine $\times$ Hair goat, Saanen $\times$ Hair goat and Hair goat male kids fed with concentrate in addition to grazing on rangeland. Small Ruminant Res. 109: 6975.

Hwangbo, S., S.H. Choi, S.W. Kim, D.S. Son, H.S. Park, S.H. Lee and I.H. Jo. 2009. Effects of crude protein levels in total mixed rations on growth performance and meat quality in growing Korean black goats. Asian-Aust. J. Anim. Sci. 22: 1133-1139.

Kadim, I.T., O. Mahgoub, D.S. Al-Ajmi, R.S. Al-Maqbaly, N.M. Al-Saqri and A. Ritchie. 2003. An evaluation of the growth, carcass and meat quality characteristics of Omani goat breeds. Meat Sci. 66: 203-210.

Kadzere, C.T. and T. Charama. 1992. Effects of dietary inclusion of crushed whole soybeans on blood serum parameters in goats. Small Ruminant Res. 11: 11-16.

Karnezos, T.P., A.G. Matches, R.L. Preston and C.P. Brown. 1994. Corn supplementation of lambs grazing alfalfa. J. Anim. Sci. 72: 783-789.

Khan, B.B., M. Younas, M. Riaz and M. Yaqoob. 2005. Breeds of Livestock in Pakistan, $3^{\text {rd }}$ Ed. Pak. TM. Printers, Faisalabad, Pakistan.

Kondaiah, N., A.S.R. Anjaneyulu, V.K. Rao, N. Sharma and H.B. Joshi. 1985. Effect of salt and phosphate on the quality of buffalo and goat meats. Meat Sci. 15: 183-192.

Lambe, N.R., E.A. Navajas, A.V. Fisher, G. Simm, R. Roehe and L. Bunger. 2009. Prediction of lamb meat eating quality in two divergent breeds using various live animal and carcass measurements. Meat Sci. 83: 366-375.

Limea, L., M. Boval, N. Mandonnet, G. Garcia, H. Archimede and G. Alexandre. 2009. Growth performance, carcass quality and noncarcass components of indigenous Caribbean goats under varying nutritional densities. J. Anim. Sci. 87: 3770-3781.

Meilgaard, M., G.V. Civille and B.T. Carr. 2007. Sensory Evaluation Techniques, $4^{\text {th }}$ Ed. CRC Press LLC, USA.

Mohammadi, Y., A. Rashidi, M.S. Mokhtari and A.K. Esmailizadeh. 2010. Quantitative genetic analysis of growth traits and Kleiber ratios in Sanjabi sheep. Small Ruminant Res. 93: 88-93.

Mudalal, M.O., I. Bushara, D.M. Mekki and S.A. Babiker. 2014. Effect of nutrition and castration on carcass measurements, wholesale cuts and carcass composition of male Desert goats. Global J. Anim. Sci. Res. 2: 97101.

Mukhtar, N., M. Sarwar, M.U. Nisa and M.A. Sheikh. 2010. Growth response of growing lambs fed on concentrate 
with or without ionophores and probiotics. Int. J. Agric. Biol. 12: 734-738.

Najafi, M.H., S. Zeinoaldini, M. Ganjkhanlou, H. Mohammadi, D.L. Hopkins and E.N. Ponnampalam. 2012. Performance, carcass traits, muscle fatty acid composition and meat sensory properties of male Mahabadi goat kids fed palm oil, soybean oil or fish oil. Meat Sci. 92: 848-854.

Nisa, M.U., M.A. Shahzad, M. Sarwar and H.A. Saddiqi. 2013. Response of growing goats to high input feeding system with or without probiotics and ionophores. Egyptian J. Sheep \& Goat Sci. 8: 45-49.

NRC. 2007. Nutrient requirements of small ruminants: sheep, goats, cervids and new world camelids. Amazon Publisher, USA.

Nudda, A., G. Battacone, G. Bomboi, B. Floris, M. Decandia and G. Pulina. 2013. Effect of dietary iodine on thyroid hormones and energy blood metabolites in lactating goats. Animal. 7: 60-65.

Oramari, R.A., J.E. Alkass and K.I. Mahmud. 2014. A comparative study on growth, carcass traits and tissue distribution of Awassi and Hamdani lambs. J. Biol. Agric. Healthcare 4: 36-43.

Ozcan, M., H. Yalcintan, C. Tolu, B. Ekiz, A. Yilmaz and T. Savas. 2014. Carcass and meat quality of Gokceada goat kids reared under extensive and semi-intensive production systems. Meat Sci. 96: 496-502.

Plant, C.L. and J.J.L. Maden. 1996. A comparison of methods for measuring eye muscle area in lamb. Proc. Aust. Soc. Anim. Prod. 21: 429.

Poore, M.H., S.R. Freeman, A.D. Shaeffer, H.M. Glennon and J.M. Luginbuhl. 2013. Influence of castration and level of intake of a commercial concentrate $(0,2 \% \mathrm{BW}$, or ad libitum) on growth performance and carcass characteristics of finishing Boer-cross meat goats. The Professional Animal Scientist 29: 242-251.

R Core Team. 2014. R: A Language and Environment for Statistical Computing. Vienna, Austria.

Ripoll, G., M. Joy, F. Munoz and P. Alberti. 2008. Meat and fat colour as a tool to trace grass-feeding systems in light lamb production. Meat Sci. 80: 239-248.

Sarwar, M., N. Mukhtar, M.A. Shahzad and M.U. Nisa. 2010. Traditional versus high input feeding system: impact on nutrients intake, blood dynamics, hormonal profile, weight gain and economics in growing lambs. Egyptian J. Sheep \& Goat Sci. 5: 127-145.
Sarwar, M., M.A. Shahzad and M.U. Nisa. 2012. Effects of feeding different level of dietary protein with or without Probiotics or Ionophores on performance of growing kids. Proc. $2^{\text {nd }}$ Int. Seminar on Animal Industry (ISAI). Jakarta, 5-6 July, pp.438-446.

Schanbacher, B.D., J.D. Crouse and C.L. Ferrell. 1980. Testosterone influences on growth, performance, carcass characteristics and composition of young market lambs. J. Anim. Sci. 51: 685-691.

Sen, A.R., A. Santra and S.A. Karim. 2004. Carcass yield, composition and meat quality attributes of sheep and goat under semiarid conditions. Meat Sci. 66: 757-763.

Sun, H.X. and D.W. Zhou. 2010. Effect of dietary supplement of seed of a halophyte (Suaeda glauca) on feed and water intake, diet digestibility, animal performance and serum biochemistry in lambs. Livestock Sci. 128: 133-139.

Talebi, M.A. 2012. Feed intake, feed efficiency, growth and their relationship with Kleiber ratio in Lori-Bakhtiari lambs. Archiva Zootechnica 15: 33-39.

Titi, H.H., R.O. Dmour and A.Y. Abdullah. 2008. Growth performance and carcass characteristics of Awassi lambs and Shami goat kids fed yeast culture in their finishing diet. Anim. Feed Sci. \& Tech. 142: 33-43.

Tripathi, M.K., D. Mondal, S.K.S. Raghuvansi and S.A. Karim. 2012. Effect of Bt-cottonseed meal feeding on intake, growth, nutrient utilization, serum cholesterol, immunological status, organ weight and slaughtering performance of growing lambs. Anim. Nutr. Feed Tech. 12: $165-178$.

Turner, K.E., S. Wildeus and J.R. Collins. 2005. Intake, performance and blood parameters in young goats offered high forage diets of lespedeza or alfalfa hay. Small Ruminant Res. 59: 15-23.

Wardlaw, F.B., L.H. McCaskill and J.C. Acton. 1973. Effect of postmortem muscle changes on poultry meat loaf properties. J. Food Sci. 38: 421-423.

Wellington, G.H., D.E. Hogue and R.H. Foote. 2003. Growth, carcass characteristics and androgen concentrations of gonad-altered ram lambs. Small Ruminant Res. 48: 5159.

Zamiri, M.J., B. Eilami and M.R. Kianzad. 2012. Effects of castration and fattening period on growth performance and carcass characteristics in Iranian goats. Small Ruminant Res. 104: 55-61. 